\title{
CLINICAL AND RADIOGRAPHIC ASSESSMENT OF TURMERIC AND ALOE BARBADENSIS MIX AS A CAPPING MATERIAL FOR PRIMARY TEETH
}

\begin{abstract}
Abdelaleem Abo Bakr Elbadrawy ${ }^{1 *}$, Alaa Aldeen Abd Allah ${ }^{2}$, Abd Elhamed Abou El yazed Eisa ${ }^{3}$
\end{abstract}
\begin{abstract}
Objective: The objective of this study was to evaluate clinically and radiographic the calcium hydroxide-formocresol mix as a root filling material in primary teeth. Materials and Methods: The study was performed on 75 primary molars of patients aged from 4-8 years that indicated for pulpectomy. The teeth were divided randomly into 3 main equal groups. Each group formed of 25 primary molars. Group A: 25 children teeth in which zinc oxide and eugenol (ZO/E) was used as filling material. Group B: 25 children teeth in which calcium hydroxide formocresol mix was used as a filling material. Group C: 25 children teeth in which Metapex was used as filling material. The teeth were assessed clinically and radiographically at 5 different intervals (preoperative, 24 hours, 6 weeks, 3 months and 6 month postoperative) using standard clinical and radiographic criteria. Results: It was found that Metapex offers best clinical and radiographic results when compared with ZO/E and calcium hydroxide formocresol mix. ZO/E (group A) showed (84\%) success rate, while the Calcium hydroxide-formocresol mix (group B) showed a higher success rate $(88 \%)$ than (ZO/E). Metapex (group c) show best success rate of all groups (94\%) while failure rate showed (16\%), (12\%) and $(6 \%)$ respectively. Conclusion: Although Metapex proved the best properties as root filling material with a highest success rate, Calcium hydroxide-formocresol mix showing competitive properties to Metapex and better results than ZO/E. Both of Metapex \& Calcium hydroxide-formocresol mix have the power to be an alternative for $\mathrm{ZO} / \mathrm{E}$ in pulpectomized primary molars.
\end{abstract}

KEYWORDS: Primary teeth, pulpectomy, ZO/E, Calcium hydroxide-formocresol mix, Metapex.

\section{INTRODUCTION}

Dental caries still the disease number one affecting children all over the world. It is not only the most common dental problem but the most common chronic childhood disease affecting the general health of children. Moreover, it does not seem to be diminishing especially in developing countries. It is a multifactorial disease result of a complex interplay of multiple determinants that may change overtime. It is continues to be a major problem in dentistry and should receive significant attention in every day practice ${ }^{(1-4)}$.

Pulpotomy is the most common technique to treat curiously exposed pulp symptom-free primary

\footnotetext{
* Masters candidate, Department of Pedodontics and Oral Health, Faculty of Dental Medicine, Boys, Cairo Al-Azhar University

** Assistant Professor, Department of Pedodontics and Oral Health, Faculty of Dental Medicine, Boys, Cairo Al-Azhar University

*** Lecturer, Department of Pedodontics and Oral Health, Faculty of Dental Medicine, Boys, Cairo Al-Azhar University
}

-Corresponding author: dr.a.elbadrawy@gmail.com 
teeth. Pulpectomy of primary teeth is good alternative treatment instead of teeth extraction in case of advanced destructive caries and failure of pulp capping and Pulpotomy. Formocresol is the material of choice and the most commonly used pulp dressing in primary teeth. So it showing high success rate of Pulpotomy However, many concerns have been expressed about formocresol toxicity and mutagenicity. Several studies have reported its potential for the local/systemic side effects, such as local effect on the enamel structure of the permanent successors, pulpal inflammation/necrosis, general cytotoxicity, mutagenic/carcinogenic effect, systemic disturbances and immunologic responses ${ }^{(5-9)}$.

Zinc oxide-eugenol paste alone or mixed with formocresol (antiseptic paste) was the popular obturator agent in primary teeth. But earlier studies revealed some negative aspects of Zinc oxide-eugenol that eugenol possesses destructive properties. Moreover, it cannot be placed directly on pulp since it shows low success rate and failure of root resorption in case of overfilling ${ }^{(10)}$.

Several materials have been used instead of formocresol and Zinc oxide-eugenol. Calcium hydroxide is one of these materials since it is able to induce the formation tissue barrier. In addition, calcium hydroxide is also capable of stimulating pulp tissue repair and presents the best pulp capping outcomes ${ }^{(11)}$. Although some investigators asserted that alternatives to calcium hydroxide should be considered because of dissolution of calcium hydroxide, recurrence of pulp inflammation and necrosis, and the presence of tunnel defects in dentin bridges formed against calcium hydroxide that increases its permeability ${ }^{(12)}$. So a viscous paste mixture of calcium hydroxide and iodoform (Metapex) was used as a root canal filling material in primary teeth. It contains iodoform (40.4\%), calcium hydroxide (30.3\%) and silicone oil $(22.4)^{(13)}$.

Calcium hydroxide-formocresol mix showed high success rates capping material in pulpotomized young permanent teeth of $\operatorname{dogs}$ and human ${ }^{(14,15)}$.
Moreover, it showed superior properties as a capping materials in human primary molars than calcium hydroxide and formocresol alone (16). However, according to the available literatures, it appears that there is nearly no data investigate this mix as root canal filling in primary teeth. Accordingly, the present study was directed to evaluate Calcium hydroxide-formocresol mix as a root canal filing in primary teeth in compare to Metapex and Zinc oxide-eugenol paste.

\section{MATERIALS AND METHODS}

This was a prospective clinical study. Patients selected from Pedodontic Outpatients Clinic, Faculty of Dental Medicine, Boys, Cairo, Al-Azhar University, age from $4-8$ years old. Seventy five badly decayed primary molars indicated for pulpectomy.

\section{Sample size}

A sample size of 25 in each group that has an $80 \%$ power has been selected to detect a difference between means of 4.60 with a significance level (alpha) of 0.05 (two-tailed).

Pulpectomy was performed in 75 badly decayed primary molars that divided into three equal groups according to material used in pulpectomy:

Group A: composed of 25 primary molars received $\mathrm{ZO} / \mathrm{E}$ as root filling material

Group B: formed of 25 primary molars received Calcium hydroxide-formocresol mix as root filling material.

Group C: consists of 25 primary molars received Metapex as a root filling material.

\section{Eligibility criteria of population}

\section{Inclusion criteria:}

Cooperative child with clinical characteristics showing one or more signs and symptoms of partial pulpectomy; teeth with deep carious pulp exposure, diagnosed as having irreversible pulpitis on basis 
of reported symptoms and/or clinical findings. (eg. profuse hemorrhage following pulpotomy procedure; tooth should be restorable; teeth showing radiographic signs of pulpal or inter-radicular involvement ranging from slight thinning of the trabeculae to furcal and/or periapical radiolucency; and apical abscess or sinus tract.

\section{Exclusion criteria:}

An uncooperative child; children with systemic diseases that can affect immunity; teeth with pre-shedding and abnormal pathologic mobility; teeth with internal/external root resorption involving permanent tooth follicle; teeth showing perforation of pulpal floor; non restorable tooth; and teeth associated with a dentigerous cyst.

\section{Preparation of Calcium hydroxide- mix:}

It was made from mixing of $1.5 \mathrm{gm}$ pure calcium hydroxide powder with $1 \mathrm{ml}$ of Buckley's formocresol (full thickness). The resulted paste ( $\mathrm{pH}$ is about 9.5) was used as a pulp capping materials in Calcium hydroxide-Formocresol pulpectomy ${ }^{(13)}$.

\section{Intervention $^{(13-20)}$}

Following local anesthetic administration, rubber dam isolation of the tooth was carried out. Dental caries and overhanging enamel were removed using at high speed with a water coolant. Access to the coronal pulp was obtained with round bur and flaring with fissure diamond stone was made sharp excavator was used if there were any remnants of necrotic material inside the canal pulp chamber. Necrotic tissue from the pulp chamber was removed using a spoon excavator. Pulpal tissue was extirpated from the root canals using $\mathrm{H}$ files.

A diagnostic radiograph with a $\mathrm{K}$ file placed in each canal was taken to ascertain the length of the root canal. The working length was kept $1.5 \mathrm{~mm}$ short of the radiographic apex to avoid over instrumentation and over oburation. The cleaning and shaping of the root canals was carried out using k file (20, 25, 30, and 35). Care was taken to selectively file the root canals. This maintained more pressure along the outer wall of the canal and not towards the generally thin interradicular area, thus minimizing the risk of perforation. Irrigation of the root canals was alternatively done with saline and $2.5 \%$ sodium hypochlorite solution. The canals were then dried with absorbent Paper points and were ready for obturation. After placement of the rot filling material tooth restored by glass ionomer cement as temporary restoration then amalgam restoration (Fig. 1).

\section{Ethical consideration}

The study was approved by the department council, ethical and scientific Committees, Faculty of Dental Medicine, Boys, Cairo, Al-Azhar University. A signed informed consent was done from the parents of each child prior to beginning the study

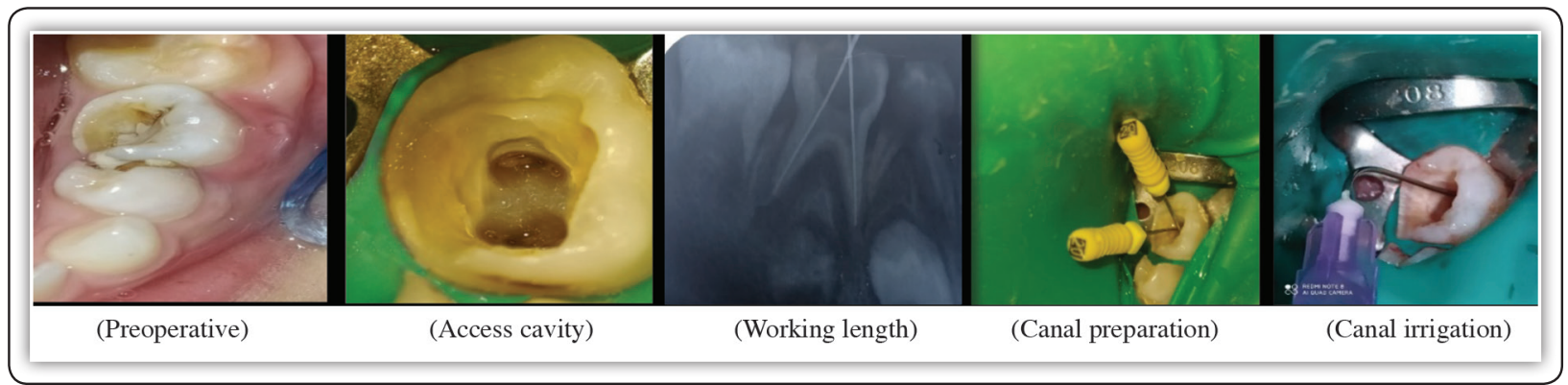

FIG (1) 7 years old male showing badly decayed lower right second primary molar was pulpectomized and treated with Calcium hydroxide FC mix as a root filling material. 


\section{Statistical Analysis:}

Data was statistically analyzed using SPSS statistical program (Statistical Package for Social Sciences) version 21 for windows. A value of $\mathrm{P} \leq 0.05$ was considered statistically significant. Chi square test and odd ratio were performed for data analysis.

\section{RESULTS}

Clinical and radiographic examinations were done preoperative, 24 hours, 6 weeks, three months and six months post-treatment. Patients' assessments were done in every visit and the success rate was regularly calculated. But the final outcome was taken after results of evaluation on last visit.

Presence of acute pain, tooth mobility, apical periodontitis (acute or chronic), radiographic evidence of internal or external resorption, widening of periodontal membrane space, apical or bifurcation radiolucent areas.

The results were analyzed using with IBM® SPSS ${ }^{\circledR}$ Statistics Version 21 software for windows. A value of $\mathrm{P} \leq 0.05$ was considered statistically significant. Chi square test and odd ratio were performed for data analysis. Sample size $(n=25 /$ group) was large enough to detect large effect sizes for main effects and pair-wise comparisons, with the satisfactory level of power set at $80 \%$ and $95 \%$ confidence level.

The cases treated were considered successful clinically if there was absence of pain, tenderness on percussion pathology, absence of swelling or fistula and absence of mobility. The cases were considered successful radiographically, when no evidence of internal or external resorption, widening of periodontal membrane space, apical or bifurcation radiolucent areas.

\section{Clinical and radiographic evaluation:}

All cases were examined for clinical and radiographic symptoms prior to the procedure that was recorded. Pre-operative and follow-up clinical factors are summarized in the table (1).

After 6 months of clinical and radiographic follow up of Zinc oxide eugenol group demonstrated 4 teeth showed abnormal radiographic features complained of pain, 2 teeth complained of tenderness to percussion and 2 tooth complained of mobility and gingival swelling [Fig. 2 Tab. 1].. Clinical and radiographic follow up of calcium hydroxide-formocresol mix group revealed that only 2 teeth complained of pain, 1 tooth complained of tenderness on percussion. These three teeth showed widening of periodontal membrane and periapical pathosis [Fig. 3 Tab. 1]. Metapex group showed only 1 tooth complained of pain and tenderness to percussion [Fig. 4 Tab. 1]. Clinically and radiographic, postoperative evaluation revealed that there was reduction in pathologic clinical signs and symptoms in all groups [Fig. 2, $3 \& 4$ Tab. 1]. Statistically there are highly significant differences pre and post treatment inside the group while the differences between the three groups were statistically insignificant (Tab. 1).

The success of the treatment was determined after follow up period of 6 months. In Metapex the success rate clinically and radiographically was $94 \%$, i.e., 24 out of 25 teeth. While in $\mathrm{CaOH}-\mathrm{FC}$ mix group it was $88 \%$, i.e., 22 out of 25 teeth, In $\mathrm{ZO} / \mathrm{E}$ the success rate clinically and radiographically was $84 \%$, i.e., 21 out of 25 teeth were considered successful as these teeth were asymptomatic and clinical as well as radiographical signs of pathology were absent (Tab. 1). 
TABLE (1): Comparative clinical evaluation between the 3 groups, preoperatively, 24hours, 6weeks, 3 months and 6months postoperatively.

\begin{tabular}{|c|c|c|c|c|c|c|c|}
\hline \multirow{3}{*}{\multicolumn{2}{|c|}{ Variables }} & \multicolumn{6}{|c|}{ Material group } \\
\hline & & \multicolumn{2}{|c|}{$\mathbf{Z O} / \mathbf{E}$} & \multicolumn{2}{|c|}{$\mathrm{CaOH}-\mathrm{FC}$ mix } & \multicolumn{2}{|c|}{ Metapex } \\
\hline & & Yes & No & Yes & No & Yes & No \\
\hline \multirow{5}{*}{ Follow up time } & Pre-operative & $\begin{array}{c}14 \\
(56 \%)\end{array}$ & $(44 \%)^{11}$ & $\begin{array}{c}16 \\
(64 \%)\end{array}$ & $\begin{array}{c}9 \\
(36 \%)\end{array}$ & ${ }^{18}{ }^{18}$ & $\begin{array}{c}7 \\
(28 \%)\end{array}$ \\
\hline & After 24hours & $\begin{array}{c}14 \\
(56 \%)\end{array}$ & $\begin{array}{c}11 \\
(44 \%)\end{array}$ & $\begin{array}{c}16 \\
(64 \%)\end{array}$ & $\begin{array}{c}9 \\
(36 \%)\end{array}$ & $\begin{array}{c}18 \\
(72 \%)\end{array}$ & $(28 \%)^{7}$ \\
\hline & After 6weeks & $\begin{array}{c}5 \\
(20 \%)\end{array}$ & $\begin{array}{c}20 \\
(80 \%)\end{array}$ & $\begin{array}{c}4 \\
(16 \%)\end{array}$ & $\begin{array}{c}21 \\
(84 \%)\end{array}$ & $\begin{array}{c}4 \\
(16 \%)\end{array}$ & $\begin{array}{c}21 \\
(84 \%)\end{array}$ \\
\hline & After 3months & $\begin{array}{c}4 \\
(16 \%)\end{array}$ & $\begin{array}{c}21 \\
(84 \%)\end{array}$ & $\begin{array}{c}3 \\
(12 \%)\end{array}$ & $\begin{array}{c}22 \\
(88 \%)\end{array}$ & $\begin{array}{c}1 \\
(6 \%)\end{array}$ & $\begin{array}{c}24 \\
(94 \%)\end{array}$ \\
\hline & After 6 months & $\begin{array}{c}4 \\
(16 \%)\end{array}$ & $\begin{array}{c}21 \\
(84 \%)\end{array}$ & $\begin{array}{c}3 \\
(12 \%)\end{array}$ & $\begin{array}{c}22 \\
(88 \%)\end{array}$ & $1(6 \%)$ & $24(94 \%)$ \\
\hline \multirow{2}{*}{$\begin{array}{c}\text { Chi square } \\
\text { Test }\end{array}$} & \multirow{2}{*}{ P value } & \multicolumn{2}{|c|}{$0.0001 *$} & \multicolumn{2}{|c|}{$0.0001 *$} & \multicolumn{2}{|c|}{$0.0001 *$} \\
\hline & & \multicolumn{6}{|c|}{$0.5921 \mathrm{~ns}$} \\
\hline
\end{tabular}

$*$ : Significant $(\mathrm{p} \leq 0.05) \quad * *$ : Highly significant $(\mathrm{p} \leq 0.01) \quad$ ns: non-significant $(\mathrm{p}>0.05)$

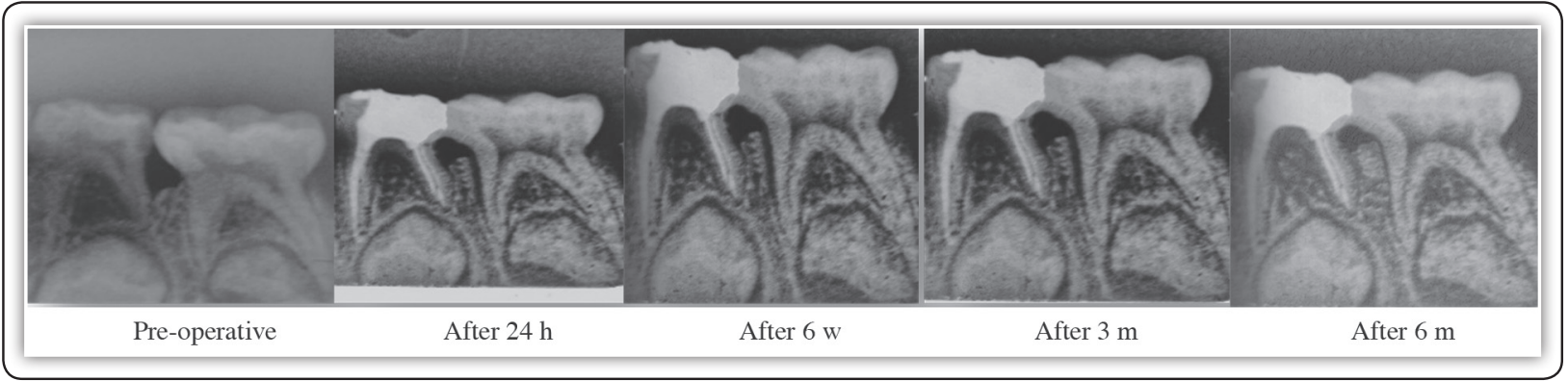

FIG (2) ZO/E pulpectomy for primary molar of boy 5 years old (group A).

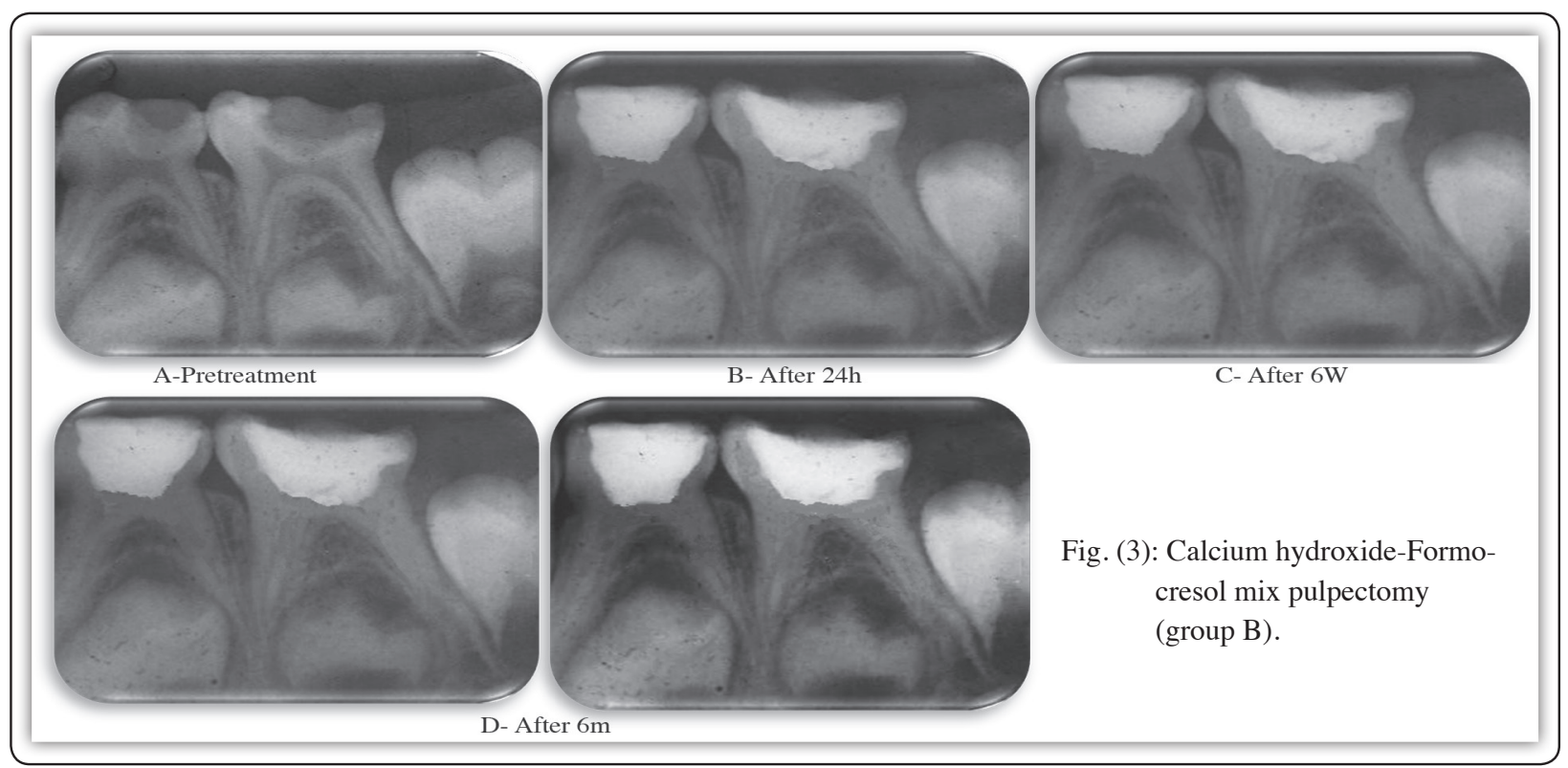




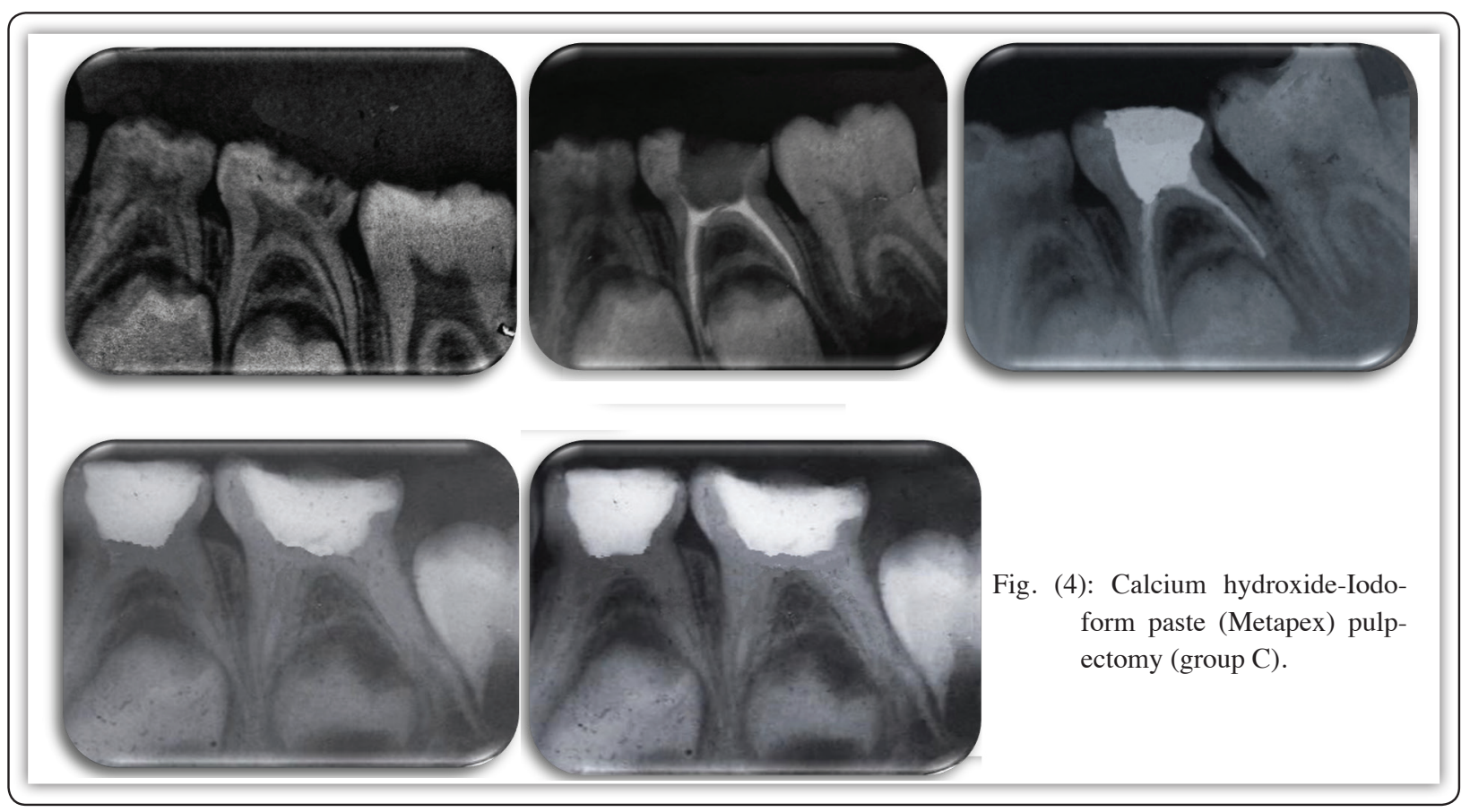

\section{DISCUSSION}

The lack of treatment of a deciduous teeth with irreversible pulpitis or pulpal necrosis can cause damage to the succedaneous teeth (e.g., enamel hypomineralization or hypoplasia) and produce negative impacts on the child's oral health related quality of life (e.g., pain, missed school days and difficulty in chewing) - Therefore, teeth presenting these conditions should be extracted or subjected to root canal treatment. Various techniques for the endodontic treatment of deciduous teeth have been described ${ }^{(16)}$.

Dental caries still the disease number one affecting children in Egypt and may be all over the world. It is one of the most common conditions affecting the general health of children. Pulpectomy is considered the last option for keeping a primary tooth that has irreversibly affected pulp tissue due to caries in a child. The aim of pulpectomy is to preserve teeth in a symptom free state until they are replaced by their successor naturally during the transition from primary to permanent dentition, thus avoiding extraction ${ }^{(17)}$.
$\mathrm{ZOE}$ is the most commonly used substance that was recommended in 2008 by the American Academy of Pediatric Dentistry (AAPD) for treatment in primary teeth ${ }^{(18) .}$ The success rate reported for ZOE varies from 65-100\%, with an average of $83 \%$, and there is no significant difference between the success rates of ZOE and calcium hydroxide or iodoform formulations ${ }^{(19)}$.

Despite several advantages of ZOE that has become the material of choice for intracanal filling, it is not an ideal one. ZOE has some disadvantages such as low resorption rate, irritation of periapical tissues, and changing the path of eruption of succedaneous tooth ${ }^{(20)}$. It may also cause necrosis of bone and cementum when be extruded beyond the apex of teeth. A lot of controversial studies have been done about success rate of different intracanal filling material, especially ZOE that almost none of them were only on necrotic teeth, For example, Holan and Fuks gave an overall success rate of $65 \%$ to ZOE as an intracanal filling material, after a 1248 month follow up ${ }^{(21)}$. Whereas Coll et al. reported a success rate of $86.1 \%$ after at least a 5-year follow up of 41 pulpectomized teeth with $\mathrm{ZOE}^{(22)}$. 
So in this study, the investigators tried to increase the success rate of calcium hydroxide and decrease the toxicity of formocresol, and avoid the disadvantage of $\mathrm{ZO} / \mathrm{E}$ reaching to a more successful, available, cheaper new filling material. The new mix results were compared to that of $\mathrm{ZO} / \mathrm{E}$ and Metapex.

In ( Group A ) ZO/E Group It was found that the success rate (absence of any clinical signs of inflammation) of this study (84\%) is nearly the same as the results of Mani et al., $200{ }^{(23)}$ who reported $83.3 \%$ success rate in follow up period of 6 months . Also the current study results are compatible with many other results as Nadkarni and Damle 2000 who reported $88.6 \%$ success rate in follow up period of 9 months ${ }^{(24)}$.

However, the study results are slightly different with the results of Zahra and Shiva Who reported 93.4\% success rate in follow up period of one year. This differences may be refereed to cases selection or individual variation ${ }^{(25)}$.

In (Group B) $\mathrm{Ca}(\mathrm{OH})_{2}$-FC mix group approximately this mix was not investigated before in primary teeth as root filling material. However, the result of this study came compatible with results of tamer El mansy et al., $2013{ }^{(16)}$ who reported 93\% clinical and radiographic success after $3 \mathrm{~m}$ follow up of calcium hydroxide-formocresol pulpotomy but with slight difference that came due this study used the mix in pulpectomized primary teeth rather than pulpotomized teeth as in his study.

Generally, although the current study was performed in primary molars but however the study results came in agreement with the results of many studies that reported $100 \%$ success rate of calcium hydroxide-Formocresol mix after $3 \mathrm{~m}$ of clinical and radiographic follow up in animal and human young permanent molars and after $3 y$ of follow up of recent exposed human young permanent teeth ${ }^{(14,15)}$. This slight difference in success rate may be referred to difference in pulp tissues reactions and techniques.
This relatively higher success rate of the mixture in compare to zinc oxide eugenol paste can be referred to:

First, the milder $\mathrm{pH}$ (9.5) of the calcium hydroxide-formocresol mix (slightly alkaline) i.e. it is less irritable than calcium hydroxide $\mathrm{pH}$ (11) and formocresol pH (4.5) alone. Consequently it is less irritable to periapical tissues than zinc oxide eugenol paste that have a similar $\mathrm{pH}$ level to calcium hydroxide. Second, the calcium hydroxide-formocresol mix may contain volatile bactericidal substances like formaldehyde coming from formocresol that disinfect the periapical tissues thus increase the success rate ${ }^{(14)}$.

In (Group C) Metapex Group It was found that the success rate of this study is (94\%) which is compatible with many studies ${ }^{(16,17)}$ that reported success rate $(100 \%)$ clinically and radiographically. The principal advantages of the Vitapex paste are that it resorbs from the apical tissues in one week to two months, is apparently harmless to permanent tooth germs, is radiopaque, does not set to a hard mass, and is easily inserted and removed (18). However this slight difference in success rate in this study may be revealed to individual variation and cases selection.

\section{CONCLUSION}

From the results of the present study, the following conclusions could be drawn:

1. Calcium hydroxide-Formocresol mix showed a highly competitive result to Metapex which showed the best results between the three groups. Moreover, it proved a better clinical and radiographic result than zinc oxide group. So it can be used as a successful root canal filling material in treatment of badly decayed deciduous teeth.

2. Calcium hydroxide-Formocresol mix could be used in the future in treatment of recently exposed traumatized deciduous teeth after further confirmative investigations. 


\section{REFERENCES}

1. Alaa A and Mousa A.Dental caries assessment in Egyptian preschool children.Egy Dent J.2013; 59: 1009-19.

2. Newacheck, P. The unmet health needs of America's children. Pediatrics 2000:105:989-97.

3. Newborn E. Current regulations and recommendations concerning water fluoridation, fluoride supplements and topical fluoride agents. J .Dent. Res. 1992:71:1255-.62

4. Mannaa A, Carlén A, Campus G, Lingström P. Supragingival plaque microbial analysis in reflection to caries experience. BMC Oral Health. 2013 ;8: 13:5.

5. Huth K, Paschos E, Hajek-Al-Khatar N, Hollweck R, Crispin A, Hickel R, et al . Effectiveness of 4 pulpotomy techniques-randomized controlled trial. J Dent Res 2005; 84 :1144-48.

6. Fuks A. Pulp therapy for the primary and young permanent dentitions. Dent Clin North Am 2000; 44:571.

7. Holan G, Eidelman E, Fuks A. Long-term evaluation of pulpotomy in primary molars using mineral trioxide aggregate or formocresol. Pediatr. Dent 2005;27:129-36.

8. Agamy H, Bakry N, Mounir M, Avery D. Comparison of mineral trioxide aggregate and formocresol as pulp-capping agents in pulpotomized primary teeth. Pediatr Dent 2004; 26:302-9.

9. Priya S , Kanupriya G, Endoflas, Zinc Oxide Eugenol and Metapex as Root Canal Filling Materials in Primary Molars - A Comparative Clinical Study J Clin Pediatr Dent 35(4): 365-370, 2011.

10. Magnusson B: Therapeutic pulpotomy in primary molars: clini-cal and histological follow-up. II. Zinc oxide-eugenol as wound dressing. Odontol Revy 1971 ; 22 :45-54,

11. Markovic D, Zivojinovic V, Vucetic M. Evaluation of three pulpotomy medicaments in primary teeth. Eur J Paediatr Dent 2005; 6:133-38

12. Cox C,subayR, OstroE,SuzukiS, SuzukiS.Tunnel defect in dentin bridge:their formation followingdirect pulp capping.Oper. dent $1996 ; 21: 1-4$.

13. Lu Y, Qin J. A comparison of the effect between Vitapex paste and antibiotic paste in apexification. Shanghai Kou Qiang Yi Xue 2004;13:449-51.
14. Alaa A, Salah M, Mohammed A, Abdel-Hafez E. Effect of calcium hydroxide- formocresol mix on pulp tissue of young permanent teeth. Egy. Dent. J. Vol. 59, No. 2: 1897 1912, 2013.

15. Tamer A, Alaa A, Mohammed A. effect of calcium hydroxide formocresol mix on pulp tissue of primary teeth. Al-Azhar J Dent Sci 2013;16: 157-64.

16. Swati, Sajid K, Varsha S, Clinical and radiographic evaluation of polyantibiotic paste and metapex for pulp therapy in primary molars , International Dental Journal of Student's Research, December 2015;3(4):184-188 .

17. Nurko C, Garcia-Godoy F. Evaluation of a calcium hydroxide/iodoform paste (Vitapex) in root canal therapy for primary teeth. J Clin Pediatr Dent. 1999 Summer;23(4):289-94.

18. Fuks AB, Kupietsky A, Guelmann M. Pulp therapy for the primary dentition, in Casamassimo P, Fields H, McTigue D, Nowak A (editors). Pediatric Dentistry: Infancy through Adolescence. Maryland Heights, Missouri, USA, Elsevier, 2013:333-51.

19. Spedding RH. Incomplete resorption of resorbable zinc oxide root canal filling in primary teeth-report of two cases. ASDC J Dentistry for Children 1985;52: 214-6.

20. Holan G1, Fuks AB. A comparison of pulpectomies using ZOE and KRI paste in primary molars: a retrospective study. J Pediatr Dent 1993; 15: 403-7.

21. Coll JA, Josell S, Casper JS. Evaluation of a one-appointment formocresol pulpectomy technique for primary molars.J Pediatr Dent 1985;7: 123-9.

22. Mani SA, Chawla HS, Tewari A, Goyal A. Evaluation of calcium hydroxide and zinc oxide eugenol as root canal filling materials in primary teeth. ASDC Journal of Dentistry for Children 2000; 67: 142-7.

23. Nadkarni U, Damle SG. Comparative evaluation of calcium hydroxide and zinc oxide eugenol as root canal filling materials for primary molars: a clinical and radiographic study. J Indian Society of Pedodontics and Preventive Dentistry 2000; 18:1-10.

24. Zahra B, Shiva Z, Success Rate of Zinc Oxide Eugenol in Pulpectomy of Necrotic Primary Molars: A Retrospective Study J Dent Mater Tech 2015; 4(2): 89-94. 